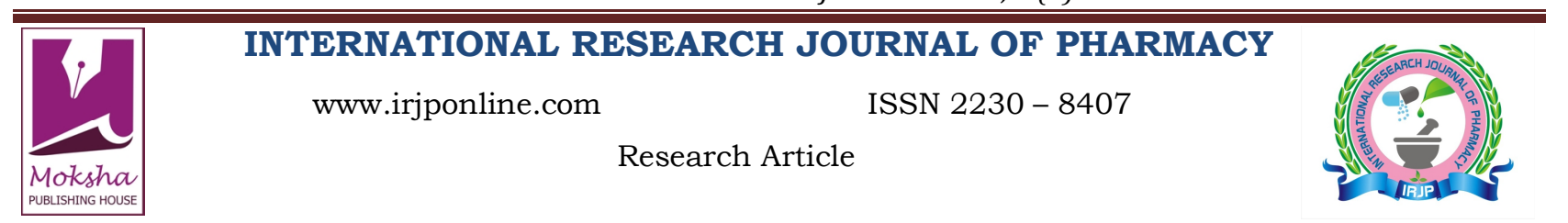

\title{
PROTECTIVE EFFECT OF ORTHOSIPHON STAMINEUS LEAVES AGAINST LEAD ACETATE AND CADMIUM CHLORIDE INDUCED RENAL DYSFUNCTION IN RATS

\author{
C.Maheswari*1, R.Venkatnarayanan ${ }^{2}$ \\ ${ }^{1}$ Department of pharmacology, R.V.S. College of Pharmaceutical Sciences, Sulur, Coimbatore, Tamilnadu, India \\ ${ }^{2}$ Department of Pharmacognosy, R.V.S. College of Pharmaceutical Sciences, Sulur,Coimbatore, Tamilnadu, India \\ Email: mahi3kp@yahoo.co.in
}

Article Received on: 11/02/13 Revised on: 09/03/13 Approved for publication: 01/04/13

DOI: 10.7897/2230-8407.4447

IRJP is an official publication of Moksha Publishing House. Website: www.mokshaph.com

(C) All rights reserved.

\begin{abstract}
Though our previous study has showed that pretreatment with Orthosiphon Stamineus methanol extract (OSM) prevents gentamycin induced nephrotoxicity. No report has been documented on the effect of Pretreatment of OSM with Cadmium and Lead. Therefore this study aims to investigating the effect of pretreatment with OSM on Cadmium and Lead induced Nephrotoxicity. Nephrotoxicity was induced in Wistar rats by intraperitoneal administration of Lead Acetate $8 \mathrm{mg} / \mathrm{kg} / \mathrm{day}$ for 21 days and oral administration of Cadmium Chloride $50 \mathrm{mg} / \mathrm{kg}$ for a single day. Effect of concurrent administration of Orthosiphon Stamineus leaf extract at a dose of $100 \mathrm{mg} / \mathrm{kg}$ and $200 \mathrm{mg} / \mathrm{kg} /$ day given by oral route was determined using serum and urinary creatinine and blood urea and Uric acid as indicators of kidney damage. The present work demonstrates that Rat chronically intoxicated with two heavy metals display a pronounced impairment in kidney function which is confirmed by the enhancement of plasma creatinine, urea and uric acid levels, and histopathological alterations. The results of the present work showed that the cortex is more affected than the medulla due to long-term treatment with heavy metals. This could be partly due to uneven distribution of heavy metals in the tissue of the kidney where about $90 \%$ of the total renal blood flow enters the cortex via the bloodstream. Orthosiphon Stamineus Leaf extract $200 \mathrm{mg} / \mathrm{kg}$ normalized the Cadmium Chloride and Lead Acetate induced increases in urine and plasma creatinine, and blood urea levels. It was observed that the Methanol extract of Orthosiphon Stamineus leaves $200 \mathrm{mg} / \mathrm{kg}$ significantly protects rat kidneys from Cadmium Chloride and Lead Acetate -induced Nephrotoxicity. Orthosiphon Leaves has protective effect on lead and cadmium induced renal toxicity. Keywords: Lead acetate; Cadmium chloride; Orthosiphon stamineus; Renal protection; Leaves
\end{abstract}

\section{INTRODUCTION}

Cadmium is a common nephrotoxic agent in food and tobacco ${ }^{2,9}$. Other major sources of cadmium are cereals, vegetables and shell fish. Cadmium mainly accumulates in the kidneys and liver. Cadmium accumulates in the renal cortex and induces tubular toxicity ${ }^{3}$. Cadmium obtained as a by-product of zinc refining, is used industrially in plating of steel, pigments, plastics, alloys, and nickel-cadmium batteries, and in nuclear and electronic engineering ${ }^{1,8}$. Because the biologic half-life of cadmium is long (more than $30 \mathrm{yr}$ ), prolonged low level exposure leads to excessive accumulation in certain tissues, especially the kidney. Studies of cadmium toxicity have been performed in the accumulator battery industry, the copper-cadmium alloy industry, and cadmium pigment factories. Chronic poisoning typically was found to have occurred after several years of exposure and was characterized clinically by variable features of naso respiratory involvement, such as emphysema, rhinitis, alteration of nasal mucosa. Yellow tooth discolouration, mild anaemia, disturbances in calcium metabolism, osteomalacia, and renal toxicity also were observed occasionally. Environmental cadmium exposure occurs in residents living in proximity to industrial pollution and also in heavy smokers, as tobacco smoke yields high cadmium concentrations. Hence the present study was undertaken to investigate the nephrotoxic effects of cadmium chloride and lead acetate on kidneys of Male wistar Rats and also to monitor the protective effect of Orthosiphon stamineus on cadmium chloride and lead acetate induced nephrotoxicity on the basis of histopathological observations.

Lead $(\mathrm{Pb})$ is a poisonous metal, which is ubiquitous in both organic (Tetraethyl lead) and inorganic (lead acetate, lead chloride) forms in environment ${ }^{15}$ and is emitted from automobile fuels, industrial discharge and paints ${ }^{11}$ Workers employed in these industries are more exposed to lead than general public ${ }^{10}$ Lead has been known as an important environmental toxicant for many years. Lead poisoning is involved in the structural and functional abnormalities of multiple organ systems. Lead is a non-threshold multitargeted toxicant that causes alterations in different organs of the body, including the kidney. The absorbed lead is conjugated in the liver and passed to the kidney, where a small quantity is excreted in urine and the rest accumulates in various body organs and interferes with their functions, specially the kidney as a target site for lead toxicity. Lead many undesired effects, including neurological, Behavioral ,renal, hepatic and reproductive dysfunctions ${ }^{16}$

Orthosiphon Stamineus commonly known as Misai kucing and widely grown in Southeast Asia . Leaves of this plant are used commonly in Southeast Asia for herbal tea, well known as "Java tea". Leaves of this plant have been used to treat rheumatism, abdominal pain, kidney and bladder inflammation, edema, gout and hypertension. Scientific studies have found that the leaves exhibit dynamic pharmacological properties such as, antioxidant, antibacterial, heptoprotective, anti-inflammatory, cytotoxic, diuretic and antihypertensive properties $5,6,16$

Though our previous study has showed that pretreatment with Orthosiphon Stamineus prevents Cisplatin induced nephrotoxicity .No report has been documented on the effect of Pretreatment of OSM with Cadmium and Lead. Therefore this study aims to investigating the effect of pretreatment with OSM on Cadmium and Lead induced nephrotoxicity. In the present experiment the animals were divided in to nine groups, each group comprised of 6 Rats were maintained in plastic cages. The first group which served as control group was administered only vehicle (water). The second and third experimental group were administered only OSM extract (100 and $200 \mathrm{mg} /$ day/animal) for 16 days. The Fourth experimental group was administered only single oral dose of 
cadmium chloride $(50 \mathrm{mg} / \mathrm{kg} /$ animal/day). The fifth and sixth experimental groups were pretreated with OSM extract for 15 days with a dose of 100 and $200 \mathrm{mg} /$ day/animal and on 16th day was administered cadmium chloride $(50 \mathrm{mg} / \mathrm{kg} / \mathrm{animal} /$ day). Histopathological observations of kidney in experimental Rats, administered single dose of $\mathrm{CdCl} 2$ distinctly revealed renal damage which was evident from significantly increase in number of degenerated and desquamation of cells in renal tubules, induction of sclerotic glomeruli. The histoarchitecture of glomeruli and renal tubules in animals co administered OSM extract and cadmium chloride showed significant decrease in number of degenerated renal tubules, desquamation of cells was less than only cadmium treated group and occurrence of normal glomeruli were seen. Hence it can be propounded that Orthosiphon Stamineus leaves can serve to check nephrotoxic effects of cadmium chloride.

\section{MATERIALS AND METHODS}

The study was conducted after taking prior approval by Institutional Animal Ethical Committee (1012 /c/06/CPCSEA), on twenty four adult male Swiss albino mice $32-50$ days old and weighing around to $30-40 \mathrm{~g}$. These were maintained in plastic cages under controlled lighting conditions (12:12 light: dark cycle) relative humidity (50 \pm $5 \%)$ and temperature $\left(37 \pm 2{ }^{\circ} \mathrm{C}\right)$, fed with mice feed and were given ad libitum access to water.

\section{Experimental Design}

Nine groups of 6 Rats per experiment were taken and treated with $\mathrm{CdCl} 2$,

Lead acetate and Orthosiphon Stamineus.. The dose protocol was as follows-

\section{Group-I}

A Control group, treated with only vehicle (water) for a day.

\section{Group-II}

A Control group treated with only OSM Extract $100 \mathrm{mg} / \mathrm{Kg} /$ day orally for 16 days.

Group-III

A Control group treated with only OSM Extract $200 \mathrm{mg} / \mathrm{Kg} /$ day orally for 16 days.

\section{Group-IV}

Experimental batch, administered $\mathrm{CdCl} 250 \mathrm{mg} / \mathrm{kg} /$ animal orally for a single day.

\section{Group-V}

Experimental batch, pre-treated with OSM extract $100 \mathrm{mg} / \mathrm{animal} /$ day orally for 15 days and on the16th day a single oral dose of $\mathrm{CdCl} 250 \mathrm{mg} / \mathrm{kg} /$ day/ animal was administered.

\section{Group-VI}

Experimental batch, pre-treated with OSM extract $200 \mathrm{mg} /$ animal/day orally for 15 days and on the16th day a single oral dose of $\mathrm{CdCl} 250 \mathrm{mg} / \mathrm{kg} / \mathrm{day} /$ animal was administered

\section{Group VII}

Control group treated with intra peritoneal (i.p.) injection of lead acetate ( $8 \mathrm{mg} / \mathrm{kg}$ ) for 21 days.

\section{Group VIII}

Experimental batch, pre-treated with OSM extract $100 \mathrm{mg} /$ animal/day for 21 days

\section{Group IX}

Experimental batch, pre-treated with OSM extract $200 \mathrm{mg} /$ animal/day for 21 days.

An hour after the treatment with Orthosiphon Stamineus, VIII and IX groups were intra peritoneally injected with lead acetate $(8 \mathrm{mg} / \mathrm{kg})$ for 21 days

Twenty-four hours after administration of last dose, the control and the experimental animals were sacrificed. Kidneys were excised and subsequently fixed in Bovins solutions. After fixation kidneys were processed, wax block and slides were prepared then stained in haematoxylin and eosin for histopathological studies.

\section{Bio- Chemical study}

Animals were sacrificed by cervical dislocation. The blood samples were collected via retro orbital puncture and the serum was used for the assay of marker enzymes viz: blood urea, serum creatinine were estimated by the method of Brod and Sirota et al ${ }^{4}$ and Marshell et al ${ }^{12}$ respectively. Levels of reduced glutathione by the method of Moron et al ${ }^{13}$ and Superoxide dismutase by Kakkar et al ${ }^{7}$ and both kidneys were isolated from each rat. The kidneys were processed for histopathological examination.

\section{Histopathology}

The kidneys were sectioned longitudinally in two halves and were kept in $10 \%$ neutral formalin solution. Both kidneys were processed and embedded in paraffin wax and sections were taken using a microtome. The sections were stained with hematoxylin and eosin and were observed under a computerized light microsope.

\section{Statistical analysis}

The results were expressed as mean \pm sem of six animals from each group. The statistical analysis was carried out by one way analysis of variance (ANOVA) $\mathrm{P}$ value $<0.05$ were considered significant.

\section{TABLE 1: EFFECT OF OSM EXTRACT ON BIOCHEMICAL PARAMETERS IN RATS SUBJECTED TO CADMIUM CHLORIDE INDUCED} NEPHROTOXICITY

\begin{tabular}{|c|c|c|c|c|c|c|}
\hline S.NO & GROUPS & TREATMENT AND DOSE & $\begin{array}{c}\text { Blood Uric acid } \\
(\mathrm{mg} / \mathrm{dl})\end{array}$ & $\begin{array}{c}\text { Serum Creatinine } \\
(\mathrm{mg} / \mathrm{dl})\end{array}$ & $\begin{array}{c}\text { Serum Urea } \\
(\mathrm{mg} / \mathrm{dl})\end{array}$ & Urine creatinine \\
\hline 1 & Group I & Control & $2.42 \pm 0.11$ & $0.37 \pm 0.03$ & $30 \pm 2.51$ & $96.71 \pm 1.54$ \\
\hline 2 & Group II & OSM Extract $100 \mathrm{mg} / \mathrm{kg}$ & $2.98 \pm 0.18$ & $0.49 \pm 0.01$ & $27.87 \pm 1.54$ & $101.6 \pm 1.22$ \\
\hline 3 & Group III & OSM Extract $200 \mathrm{mg} / \mathrm{kg}$ & $2.54 \pm 0.36$ & $0.39 \pm 1.91$ & $32.15 \pm 1.64$ & $102.4 \pm 1.23$ \\
\hline 4 & Group IV & $\mathrm{CdCl} 250 \mathrm{mg} / \mathrm{kg}$ & $7.7 \pm 1.91$ & $0.98 \pm 0.38$ & $64.60 \pm 0.07$ & $281 \pm 2.06$ \\
\hline 5 & Group V & OSM $100 \mathrm{mg} / \mathrm{kg}$ andCdCl $250 \mathrm{mg} / \mathrm{kg}$ & $4.4 \pm 1.54$ & $0.78 \pm 0.07$ & $50.42 \pm 1.52$ & $139.9 \pm 0.86$ \\
\hline 6 & Group VI & OSM $200 \mathrm{mg} / \mathrm{kg}$ and $\mathrm{CdCl} 250 \mathrm{mg} / \mathrm{kg}$ & $3.25 \pm 2.05$ & $0.57 \pm 0.02$ & $37.40 \pm 0.97$ & $131.24 \pm 0.54$ \\
\hline
\end{tabular}

Values are mean \pm sem of 6 animals in each groups. Group IV compared with group I ( $\mathrm{P}<0.001)$ Group II and III compared with Group IV ( $\mathrm{P}<0.001)$.

Group V and VI compared with IV $(\mathrm{P}<0.001)$ (ONE WAY ANOVA) 
C.Maheswari et al. Int. Res. J. Pharm. 2013, 4 (4)

TABLE 2: EFFECT OF OSM EXTRACT ON BIOCHEMICAL PARAMETERS IN RATS SUBJECTED TO LEAD ACETATE INDUCED NEPHROTOXICITY

\begin{tabular}{|c|c|c|c|c|c|c|}
\hline S.NO & GROUPS & TREATMENT AND DOSE & $\begin{array}{c}\text { Blood Uric } \\
\text { acid (mg/dl) }\end{array}$ & $\begin{array}{c}\text { Serum Creatinine } \\
(\mathrm{mg} / \mathrm{dl})\end{array}$ & $\begin{array}{c}\text { Serum Urea } \\
(\mathrm{mg} / \mathrm{dl})\end{array}$ & $\begin{array}{c}\text { Urine } \\
\text { Creatinine }\end{array}$ \\
\hline 1 & Group I & Control & $2.42 \pm 0.11$ & $0.37 \pm 0.03$ & $30 \pm 2.51$ & $96.71 \pm 1.54$ \\
\hline 2 & Group VII & Lead acetate $8 \mathrm{mg} / \mathrm{kg}$ & $6.54 \pm 1.34$ & $0.93 \pm 0.05$ & $59.96 \pm 1.64$ & $199.2 \pm 0.86$ \\
\hline 3 & Group VIII & OSM $100 \mathrm{mg} / \mathrm{kg}$ and Lead Acetate $8 \mathrm{mg} / \mathrm{kg}$ & $3.52 \pm 0.91$ & $0.47 \pm 0.04$ & $38.20 \pm 0.10$ & $141.24 \pm 0.67$ \\
\hline 4 & Group IX & OSM $200 \mathrm{mg} / \mathrm{kg}$ and Lead Acetate $8 \mathrm{mg} / \mathrm{kg}$ & $3.13 \pm 0.12$ & $0.46 \pm 0.05$ & $32.09 \pm 0.41$ & $128.53 \pm 0.92$ \\
\hline
\end{tabular}

Values are mean \pm sem of 6 animals in each groups. Group II compared with group I ( $\mathrm{P}<0.001)$ Group III and IV compared with Group II (P<0.001). (ONE WAY ANOVA)

TABLE 3: REDUCED GLUTATHIONE (GSH) AND SOD LEVEL IN CONTROL, CdCI2 AND OSM TREATED RATS

\begin{tabular}{|c|c|c|c|c|}
\hline S.NO & GROUPS & TREATMENT AND DOSE & GSH & SOD \\
\hline 1 & Group I & Control & $35.33 \pm 1.02$ & $100.42 \pm 1.38$ \\
\hline 2 & Group II & Cd Cl $50 \mathrm{mg} / \mathrm{kg}$ & $17.66 \pm 1.32$ & $53.31 \pm 1.96$ \\
\hline 3 & Group III & OSM $100 \mathrm{mg} / \mathrm{kg}$ and CdCl $50 \mathrm{mg} / \mathrm{kg}$ & $30.12 \pm 2.22$ & $62.29 \pm 1.78$ \\
\hline 4 & Group IV & OSM $200 \mathrm{mg} / \mathrm{kg}$ and CdCl $50 \mathrm{mg} / \mathrm{kg}$ & $32.21 \pm 0.87$ & $72.82 \pm 2.48$ \\
\hline
\end{tabular}

Values are mean \pm sem of 6 animals in each groups. Group II compared with group I $(\mathrm{P}<0.001)$ Group III and IV compared with Group II (P<0.001). (ONE WAY ANOVA)

TABLE 4: REDUCED GLUTATHIONE (GSH) AND SOD LEVEL IN CONTROL, LEAD ACETATE AND OSM TREATED RATS

\begin{tabular}{|c|c|c|c|c|}
\hline S.NO & GROUPS & TREATMENT AND DOSE & GSH & SOD \\
\hline 1 & Group I & Control & $35.33 \pm 1.02$ & $100.42 \pm 1.38$ \\
\hline 2 & Group II & Lead Acetate $8 \mathrm{mg} / \mathrm{kg}$ & $19.33 \pm 0.79$ & $56.82 \pm 0.78$ \\
\hline 3 & Group III & OSM $100 \mathrm{mg} / \mathrm{kg}$ and Lead Acetate $8 \mathrm{mg} / \mathrm{kg}$ & $28.14 \pm 0.97$ & $82.65 \pm 1.26$ \\
\hline 4 & Group IV & OSM $200 \mathrm{mg} / \mathrm{kg}$ and Lead Acetate $8 \mathrm{mg} / \mathrm{kg}$ & $33.33 \pm 1.12$ & $95.14 \pm 1.07$ \\
\hline
\end{tabular}

Values are mean \pm sem of 6 animals in each groups. Group II compared with group I $(\mathrm{P}<0.001)$ Group III and IV compared with Group II (P<0.001). (ONE WAY ANOVA)

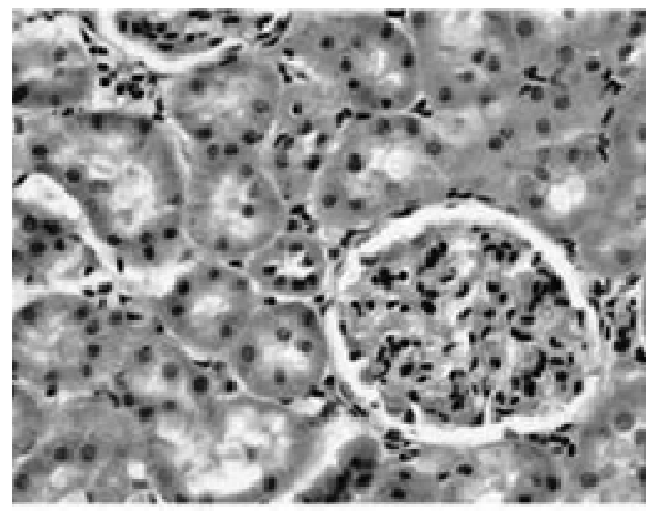

Figure 1: Histopathology of normal kidney section

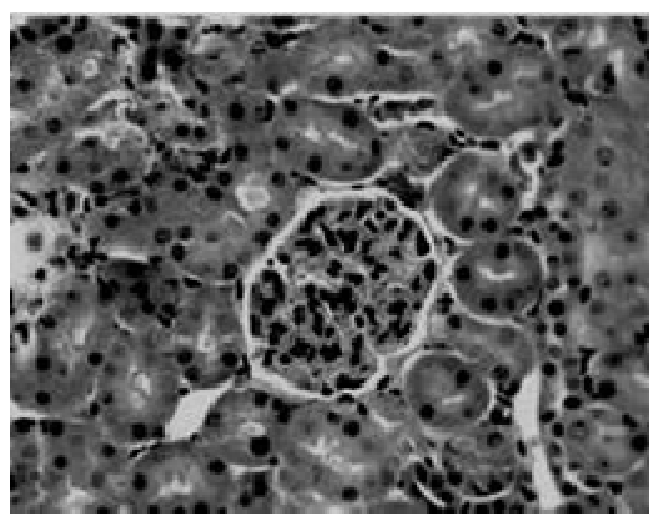

Figure 3 Histopathology of kidney treated with $\mathrm{CdCl} 2$ and $200 \mathrm{mg} / \mathrm{kg}$ OSM extract

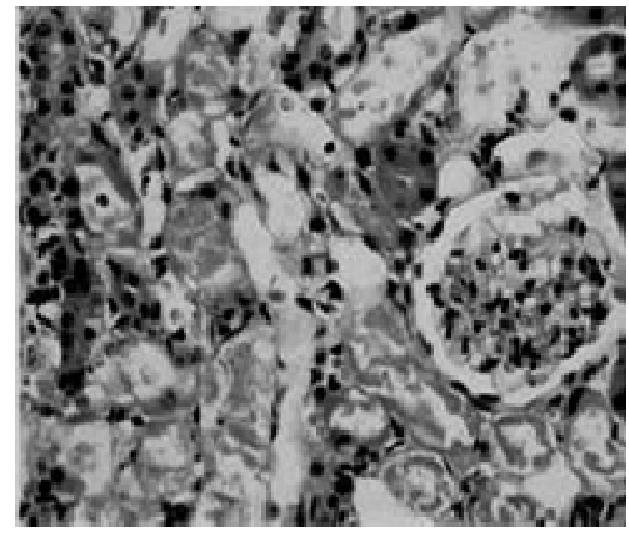

Figure 2: Histopathology of $\mathrm{CdCl} 2$ treated section

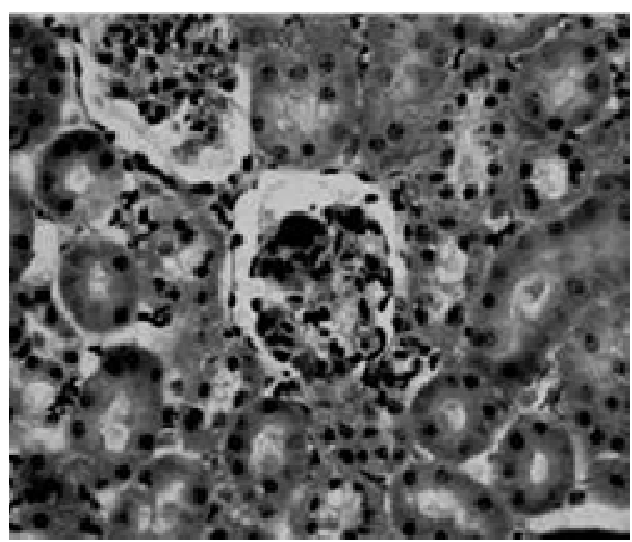

Figure 4 Histopathology of kidney treated with Lead Acetate and $200 \mathrm{mg} / \mathrm{kg}$ OSM extract 


\section{RESULTS AND DISCUSSION}

The present study was conducted to evaluate the possible protective effect of Orthosiphon Stamineus leaves against the toxicological disorders induced by Cadmium Chloride and Lead Acetate in Male Wistar Rats particularly on Kidney. It is well known that heavy metals are widely distributed in environment and some of them can cause physiological, biochemical and histological disorders. Humans are exposed to these metals from numerous sources, including contaminated air, water, soil and food. Therefore, the evaluation of toxic potentials of metals is important for the risk assessment of human beings ordinarily exposed to these substances. The present work demonstrates that Rat chronically intoxicated with two heavy metals display a pronounced impairment in kidney function which is confirmed by the enhancement of plasma creatinine, urea and uric acid levels, and histopathological alterations. The results of the present work showed that the cortex is more affected than the medulla due to long-term treatment with heavy metals. This could be partly due to uneven distribution of heavy metals in the tissue of the kidney where about $90 \%$ of the total renal blood flow enters the cortex via the bloodstream. Accordingly, a relatively high concentration of these metals might reach the cortex via the bloodstream than that would enter the medulla.

Several studies demonstrated a significant enhancement of blood creatinine, urea and uric acid concentrations, and renal histological alterations in experimental animals intoxicated with $\mathrm{Pb}, \mathrm{Cd}$, and other heavy metals. From the present results, it is obvious that treating heavy metals-intoxicated rats with Orthosiphon Stamineus leaves significantly protected the kidney structure and function as compared to the controls. These observations were confirmed by insignificant alterations in the levels of plasma creatinine, urea and uric acid, kidney GSH and SOD, and an appearance of normal structures of kidney, specially renal corpuscles, Orthosiphon Stamineus Leaf Extract may be beneficial in reducing and slowing progressive kidney diseases that are significantly accelerated by oxidative stress. Additionally, demonstrated that the treatment with Orthosiphon Stamineus significantly reduced the changes caused by $\mathrm{Cd}$ and $\mathrm{Lb}$ exposure in all examined parameters. Moreover, suggested that these results indicate that alterations caused by $\mathrm{Cd}$ and $\mathrm{Pb}$ are connected with free radicals generation and used antioxidants effectively to protect against $\mathrm{Cd}$ and $\mathrm{Pb}$ intoxication.

In conclusion, the present study showed that Orthosiphon Stamineus leaves has protective effect on lead and cadmium induced renal toxicity. This study therefore suggests that Orthosiphon Stamineus leaves may be a useful preventive agent against the effect of the studied heavy metals.

\section{REFERENCES}

1. Adams RG, Harrison JF, Scott P.et al "The development of cadmium induced proteinuria, impaired renal function, and osteomalacia in alkaline battery workers". Q J Med;1969; 38 : 425-43. PMid:5355536

2. Bachelet M, Pinot F, Polla RI, Francois D, Richard MJ, VayssierTaussat M, et al. "Toxicity of cadmium in tobacco smoke: protection by antioxidants and chelating resins". Free Radic Res; 2002; 36 : 99-106. http://dx.doi.org/10.1080/10715760210159 PMid:11999708

3. Barbier O, Dauby G " Zinc and Cadmium interactions in a renal celll line derived from rabbit proximal tubule" Nephron Physiol; 2005; 99;7484. http://dx.doi.org/10.1159/000083413 PMid:15665557

4. Brod, J. and Sirota, J. H. Practical Clinical Biochemistry (eds Varley, H. et al.), William Heinman Medical Books Ltd, London, vol. 1, 1980;pp.; 456-460

5. Chen CP, Lin CC, Namba T.et al "Screening of Taiwanese crude drugs for antibacterial activity against Streptococcus mutans". J Ethnopharmacol.; 1989;27(3):285-95; http://dx.doi.org/10.1016/03788741(89)90003-2

6. Chun-Hoong Ho, Ismail Noryati, Shaida-Fariza Sulaiman, Ahmad Rosma.et al "In vitro antibacterial and antioxidant activities of Orthosiphon stamineus Benth. extracts against food-borne bacteria". Food Chemistry;2010;22; 1168-1172

7. Kakkar P., Das B., Viswanathan P. N: A modified spectrophotometeric assay of superoxide dismutase. Ind Biochem Biophys., 1984; 21: 130132 ;

8. Kazantzis G, Flynn FV, Spowage JS, Trott DG.et al "Renal tubular malfunction and pulmonary emphysema in cadmium pigment workers. Q J Med 1963; 32 : 165-92.

9. Friberg L. Cadmium and the kidney". Environ Health Perspect 1984;54 : $1-11$

10. Landsberger $\mathrm{S}$, Larson $\mathrm{S}$, Wu $\mathrm{D}$. et al "Determination of airborne cadmium in environmental tobacco smoke by industrial neutron activation analysis with a Compton suppression system" Anal Chem; 65 : 1506-9;1993 http://dx.doi.org/10.1021/ac00059a004 PMid:8328669

11. Levin SM, Goldberg M.et al "Clinical evaluation and management of lead exposed construction workers". Am J Ind Med;37:23-43;2000 http://dx.doi.org/10.1002/(SICI)1097-0274(200001)37:1<23::AIDAJIM4>3.3.CO;2-L

12. Mahaffey KR, Fowlert BA. "Effects of concurrent administration of lead, cadmium, and arsenic in the rat". Environmental Health Perspectives;19:165-71;1977 http://dx.doi.org/10.1289/ehp.7719165 PMid:198203 PMCid: 1637428

13. Moron, M.S., Depierre, J.W., Mannervik, B et al . Levels of glutathione, glutathione reductase and glutathione S-transferase activities in rat lung and liver. Biochimica et Biophysica ACTA 582, 67-78;1979 http://dx.doi.org/10.1016/0304-4165(79)90289-7

14. Rubio J, Riqueros MI, Gasco M, Yucra S, Miranda S, Gonzales GF.et al "Lepidium meyenii (Maca) reversed the lead acetate induced damage on reproductive function in male rats". Food Chem Toxicol.; 44:111422;2006 http://dx.doi.org/10.1016/j.fct.2006.01.007 PMid:16510228

15. Shalan MG, Mostafa MS, Hassouna MM, Nabi SE, Rafie A.et al "Amelioration of leadtoxicity on rat liver with vitamin $\mathrm{C}$ and silymarin supplements". Toxicology;206:1 15;2005

16. Yam MF, Asmawi MZ, Basir R. et al "An investigation of the antiinflammatory and analgesic effects of Orthosiphon stamineus leaf extract". J Med Food ;2008. Jun;11(2):36

Cite this article as:

C.Maheswari, R.Venkatnarayanan. Protective effect of Orthosiphon stamineus leaves against lead acetate and cadmium chloride induced renal dysfunction in rats. Int. Res. J. Pharm. 2013; 4(4):232-235 